\title{
PEMIKIRAN SEYYED HOSSEIN NASR: KONSEP KEINDAHAN DAN SENI ISLAMI DALAM DUNIA PENDIDIKAN ISLAM
}

\author{
Titin Nurhidayati \\ Fakultas Tarbiyah, IAI Al - Falah As - sunniyyah Kencong \\ Titinnurhidayati77@gmail.com
}

\begin{abstract}
In the realization of education, action or work is a realization of reason. Intellect works to understand truth in its entirety, through the mind that thinks of nature, human beings and history, while through qolbuits, it understands God's words and the sunnah of God in the life of the universe. This action is basically a creative act, because it is stored in the process of creation. Creative actions basically cannot be separated from values, both aesthetic, logical and ethical values. In the practice of creating educational institutions it has a beauty value. Then the value of logic provides a demand for composing concepts and work plans that make sense. Whereas ethical values provide limitations so that creative actions remain in moral insight and for moral purposes.
\end{abstract}

Keywords: the concept of beanty, Islamic art, Islamic veligious education

\begin{abstract}
ABSTRAK
Dalam perwujudan pendidikan, perbuatan atau kerja merupakan realisasi akal. Akal bekerja untuk memahami kebenaran secara utuh, melalui pikiran yang memikirkan alam, manusia dan sejarah, sedangkan melalui qolbu-nya, ia memahami firman-firman Tuhan dan sunnah Allah dalam kehidupan alam semesta. Perbuatan ini pada dasarnya adalah perbuatan kreatif, karena tersimpan dalam proses penciptaan. Perbuatan kreatif pada dasarnya tidak dapat dipisahkan dengan nilai-nilai, baik nilai estetika, logika ataupun etika. Dalam praktek penciptaan lembaga-lembaga pendidikan itu mempunyai nilai keindahan. Kemudian nilai logika memberikan tuntutan untuk menyusun konsep dan rencana-rencana kerja yang masuk akal. Sedangkan nilai etika memberikan batasan-batasan agar perbuatan kreatif itu tetap berada dalam wawasan moral dan untuk tujuan moral.
\end{abstract}

Kata Kunci: konsep keindahan, seni islam, pendidikan agama islam

FALASIFA, Vol. 10 Nomor 1 Maret 2019 | 27 
Titin Nurhidayati

\section{PENDAHULUAN}

Dominasi yang terjadi dalam pola pikir masyarakat modern adalah model positivistik yang menggunakan ukuran sebuah kebenaran menggunakan kacamata pengetahuan empiris dan rasional. Positivisme akan menolak cara orang lama berfikir, di mana pengalaman yang sehari-hari dan perasaan religius saling meresapi, dan agama merupakan penafsiran dan pengertian yang benar ${ }^{1}$. Yang nyata adalah yang material. Nilai-nilai dan pengetahuan yang bersifat material tumbuh pesat jauh melampaui hal-hal yang bersifat spiritual, sehingga masyarakat kehilangan keseimbangan.

Kenyataan di atas tidak dapat terelakkan juga berdampak pada dunia seni atau estetika. Masuknya pandangan sekuler ke dalam dunia seni selain menambah beraneka ragamnya hasil kreasi seniman, juga berdampak buruk terhadap eksistensi seni itu sendiri². Seni yang seharusnya sarat dengan makna-makna spiritual, mengemban pesan yang tinggi dengan media manifestasi masingmasing, menjadi tergradasi dan gersang makna. Yang ada hanyalah seni untuk seni yang hanya memburu kebebasan material ekspresi dengan mengabaikan substansi makna dan pesan moral yang tinggi dalam ekspresi itu.

Pandangan ini muncul abad 18 dalam khazanah filsafat seni Eropa dengan istilah disini terestednes atau tanpa kepentingan Yang dimaksud dengan tanpa kepentingan adalah bahwa karya seni itu bebas dari kungkungan ruang dan waktu tertentu, atau konteks dan pengaruh tertentu, sehingga karya seni menemukan nilai universalnya melampaui batas-batas yang ada dan abadi.

Telah banyak karya seni modern yang melukis dengan media badan dengan kebebasannya tanpa menghiraukan norma-norma dan etika yang ada, menjadi tren yang mengkhawatirkan. Alasan melakukan hal tersebut adalah kebebasan berekspresi. Akan tetapi tanpa dasar spiritual yang dilandasi intelektual yang jelas. Hal ini tidak dapat dihindari berdampak terhadap masyarakat Islam. Sumber spiritual Islam dari Al-Qur'an dan Sunnah telah banyak terlupakan. Para seniman cenderung sekuler melakukan ekspresi estetisnya ${ }^{3}$.

Dalam kaitannya dengan kenyataan di atas, hadir seorang pemikir kontemporer bernama Seyyed Hossein Nasr banyak memberikan kritik atas kenyataan manusia modern saat ini dari berbagai segi. Salah satu fokus kritiknya adalah masalah fenomena seni modern yang sedang berkembang pesat ke seluruh

\footnotetext{
${ }^{1}$ Loren Bagus, Kamus Filsafat, (Jakarta: Gramedia, 2000), hlm. 858.

${ }^{2}$ Haedar Nashir, Agama dan Krisis Kemanusiaan Modern, (Yogyakarta: Pustaka Pelajar,1999), 4.

${ }^{3}$ Jakob Sumardjo, Filsafat Seni, (Bandung: Penerbit ITB, 2000), 47.
}

28 | FaLASIFA, Vol. 10 Nomor 1 Maret 2019 
bagian masyarakat, termasuk masyarakat Islam ${ }^{4}$.

Seyyed Hossein Nasr merupakan salah satu juru bicara Islam di Barat yang gigih menyuarakan pemikiran Tradisionalisme untuk membentengi arus modernisasi yang telah merusak sendi-sendi tradisi luhur masyarakat khususnya Islam. Sekularisasi seni saat ini juga dirasakan masyarakat Indonesia dengan berbagai fenomena bahwa seni tidak lagi mempunyai pesan dari Dunia atas, melainkan hanya sebagai bahan hiburan yang temporal dan terkadang sebagai barang dagangan murahan tanpa memperhatikan tujuan seni sebagai medium antara materialisme dunia dan kerohanian yang kekal.

\section{PEMBAHASAN}

\section{Memahami Konsep Keindahan dan Seni Islami}

\section{Teori Metafisis tentang Seni}

Konsep seni Islami Seyyed Hossein Nasr sebenarnya dengan sangat jelas merujuk pada teori seni metafisis yang pertama kali dikenalkan oleh Plato (428348 SM). Hal ini sebagai konsekuensi logis dari aliran filsafat Plato yang berpaham idealisme. Plato mendasarkan teori seninya pada metafisikanya tentang kenyataan (reality) dan kenampakan (appearance). ${ }^{5}$

Dalam perjalanan filsafatnya, Nasr berpendapat bahwa kenyataan yang berada ditingkat paling tinggi adalah berupa kenyataan ilahiah yang berupa dunia ide atau Bentuk Yang Sempurna. ${ }^{6}$ Dengan demikian bentuk yang sempurna adalah sebuah Bentuk Yang Mutlak dan kebenarannya tidak dapat diragukan lagi. Bentuk Mutlak ini bersifat abadi dan tidak terikat oleh ruang dan waktu. Hal ini berbeda sama sekali dengan bentuk yang terbatas yang berada di tingkatan dunia rendah, yang tidak abadi dan sangat tergantung pada ruang dan waktu. Bentuk yang demikian hanyalah penampakan semu dari dunia ide, yaitu kenyataan duniawiah. Sehingga dia bukanlah bentuk yang sesungguhnya. Apa yang terlihat dengan indera di dunia ini hanyalah sebuah kenyataan semu yang bukan merupakan bentuk sebenarnya.

Memang teori ini ini sangatlah rumit untuk dijelaskan. Pandangan semacam ini sangatlah abstrak dan berada di awang-awang dan memerlukan perenungan intelektual yang mendalam. Teori ini sering dikatakan teori yang yang tanpa pijakan, sangatlah bertentangan dengan para penganut positivisme yang biasanya dipakai oleh orang-orang modern. Barangkali inilah yang menjadi ciri khas para

${ }^{4}$ Ali Maksum, Tasawnf Sebagai Pembebasan Manusia Modern: Telaah Signifikansi Konsep Tradisionalisme Seyyed Hossein Nasr, (Yogyakarta: Pustaka Pelajar, 2003), 23.

${ }^{5}$ The Liang Gie, Filsafat Seni: Sebuah Pengantar, (Yogyakarta: PUBIB, 2005), 21.

${ }^{6} \mathrm{Ibid}$, 
Titin Nurhidayati

pemikir tradisionalis yang lebih mengedepankan pandangan metafisis. Nasr mengatakan bahwa hal inilah yang menjadi ciri khas Timur yang tidak dimiliki oleh masyarakat modern yang dipelopori Barat.

\section{Klasifikasi Seni (Seni Suci, Seni Tradisional dan seni religius)}

Dalam pandangan Nasr tentang hubungan antara seni dan agama, membagi seni dalam tiga wilayah, pertama adalah seni suci, yaitu seni yang berhubungan langsung dengan praktik-praktik utama agama dan kehidupan spiritual. Lawannya adalah seni profan. Kedua, seni tradisional, yaitu seni yang menggambarkan prinsip-prinsip agama dan spiritual tetapi dengan cara tidak langsung. Lawannya adalah seni anti-tradisional. Perbedaan antara seni suci dan seni tradisional ini bisa dilihat pada contoh sebuah pedang. Pedang yang dibuat Abad Pertengahan, baik Islam maupun Kristen, tidak pernah digunakan secara langsung dalam acara ritual keagamaan meski merefleksikan prinsip dan ajaran Islam atau Kristen. Karena itu, ia masuk kategori seni tradisional. Ini berbeda dengan pedang Shinto di Kuil I Se di Jepang. Pedang Shinto dikaitkan langsung dengan ajaran agama tersebut dan meruoakan objek ritual yang bermakna tinggi dalam agama Shinto sehingga dimasukkan sebagai seni suci. Ketiga, seni religius, seni yang subjek atau fungsinya bertema keagamaan, namun bentuk dan cara pelaksanaannya tidak bersifat tradisional. Masuk dalam kategori ini adalah lukisanlukisan religius dan arsitektur Barat sejak Renaisance dan beberapa lukisan religius di dunia Timur selama seabad atau dua abad lalu di bawah pengaruh seni Eropa. ${ }^{7}$

Lebih lanjut Nasr mendefinisikan seni suci dan seni tradisional sebagai berikut:

“... Seni suci adalah seni yang berhubungan langsung dengan praktikpraktik utama agama dan kehidupan spiritual, yang mencakup seni-seni seperti kaligrafi, arsitektur masjid, dan tilawah Al-Qur'an. Seni tradisional Islam, bagaimanapun juga, meliputi setiap bentuk seni yang dapat dilihat dan didengar mulai dari seni pertamanan hingga puisi, ${ }^{8}$ Seluruh bentuk seni tradisional yang juga melukiskan prinsip-prinsip wahyu Islam dan spiritualitas Islam namun dalam cara yang lebih tidak langsung. Dalam beberapa hal, seni suci merupakan inti dari seni tradisional, yang secara langsung menggambarkan prinsip-prinsip dan norma-norma yang justru terefleksikan secara tidak langsung dalam seni tradisional"'.

${ }^{7}$ Nasr, Spiritualitas....hlm. 15.

${ }^{8}$ Seyyed Hossein Nasr, Tentang Tradisi dalam Perenialisme: Melacak Jejak Filsafat Abadi, (ed.) Ahmad Norma Permata (Yogyakarta: Tiara Wacana, 1996), hlm. 146-147.

${ }^{9}$ Nasr, Spiritualitas.... hlm. 13.

$30 \mid$ FaLASIFA, Vol. 10 Nomor 1 Maret 2019 
Pembedaan atas jenis seni di atas sebenarnya merujuk pada pandangan $\mathrm{F}$. Schuon sebagai berikut:

"Semua seni suci adalah seni tradisional tapi tidak semua seni tradisional merupakan seni suci. Seni suci terletak pada jantung seni tradisional dan berkaitan secara langsung dengan wahyu dan teofani yang menyatakan inti tradisi. Seni suci melibatkan praktek-praktek ritual dan pemujaan, dan aspek praktis dan operatif dari jalan perwujudan, di mana spiritual di dasar tradisi tersebut. dalam kerangka peradaban tradisional tanpa keraguan suatu pembedaan dibuat antara seni suci dan profan. Tujuan seni suci untuk mengkomunikasikan kebenaran spiritual dan di pihak lain, kehadiran surgawi; seni suci dalam prinsipnya mempunyai fungsi yang benar-benar suci. ${ }^{\prime 10}$

Dengan demikian seni tradisional Islam bukan sebuah seni kuno atau klasik yang dibuat orang-orang sebelum masa modern. Tapi ia lebih merupakan sebuah prinsip seni yang mendasarkan diri pada sebuah pandangan metafisis. Ia merupakan sebuah media yang memanifestasikan sebuah pegangan hidup yang membawa manusia kembali ke ftrahnya sebagai makhluk ciptaan Allah. Segala sesuatu yang wujud sebenarnya adalah gema proses penciptaan yang dilakukan oleh Tuhan.

\section{Fungsi Spiritual Seni Islam}

Sebagai suluk atau perjalanan mendaki dari alam rendah (alam nasut) ke alam tinggi (alam lahut), para sufi memberikan ungkapan estetik dalam sastra dan seni mempunyai peranan atau fungsi karya seni diantaranya:

a. Fungsi Tawajjjud, yaitu membawa penikmat mencapai keadaan jiwa yang damai (mutmainah) dan menyatu dengan keabadian dari Yang Abadi. Ini dikemukakan antara lain oleh Imam al-Ghazali;

b. Fungsi Tajarrud, yaitu pembebasan jiwa dari alam benda melalui sesuatu yang berasal dari alam benda itu sendiri. Misalnya suara, bunyi-bunyian, gambar, lukisan dan kata-kata. Ini dikemukakan antara lain oleh Ruzbihan al-Baqli (abad ke-13 M).

c. Fungsi Tadzkiya al-nafs, yaitu penyucian diri dari pemberhalaan terhadap bentuk-bentuk melalui bentuk-bentuk itu sendiri. Ini dinyatakan antara lain oleh Jalaluddin Rumi, sebagaimana terekam dalam sajaknya yang telah dikutip;

d. Fungsi seni yang lain pula ialah untuk menyampaikan hikmah, yaitu kearifan

${ }^{10}$ Seyyed Hossein Nasr, Intelegensi dan Spiritualitas Agama-agama. Terj. Suharsono dkk, (Jakarta: Inisiasi Press, 2004), hlm. 289.

FALASIFA, Vol. 10 Nomor 1 Maret 2019 | 31 
Titin Nurhidayati

yang dapat meembantu kita bersikap adil dan benar terhadap tuhan, sesama manusia, lingkungan sosial, alam tempat kita hidup dan diri kita sendiri. Banyak dikemukakan para filsuf dan sastrawan seperti: Ibnu al-Muqaffa', alJahiz, Ibnu Sina, Abu A'la al-Ma'arri, Abu al-Atahiyah dan Mulla Sa'adi;

e. Seni juga berfungsi sebagai sarana efektif menyebarkan gagasan, pengetahuan, informasi yang berguna bagi kehidupan seperti pengetahuan dan informasi berkenaan sejarah, geografi, hukum, undang-undang, adab, pemerintahan, politik, ekonomi dan gagasan keagamaan. Para ilmuwan, ahli adab, ulama fiqih dan usuluddin, serta ahli tasawuf berpegang pada pendapat ini;

f. Karya seni juga dicipta untuk menyampaikan puji-pujian kepada Yang Satu. ${ }^{11}$

Sedangkan menurut The Liang Gie, sebuah karya seni setidaknya mengandung empat fungsi, yaitu fungsi spiritual, fungsi hedonistik (kenikmatan atau kesenangan), fungsi edukatif, dan fungsi komunikatif. Dengan fungsi-fungsi yang lebih lengkap, seni dapat menjadi perlengkapan manusia yang bersifat abadi dan universal. ${ }^{12}$

Tidak berbeda dengan itu, menurut Husein Nasr, seni Islam juga mengandung fungsi-fungsi tertentu. Pertama, untuk mengalirkan barakah dan kedamaian sebagai akibat hubungan batinnya dengan dimensi spiritual. Tidak bisa diingkari bahwa seorang Muslim yang paling modern atau sekuler sekalipun akan mengalami rasa damai dan kegembiraan dalam lubuk hatinya, semacam ketenangan psikologis, ketika memandang kaligrafi, duduk di atas karpet tradisional, mendengarkan dengan khusyuk bacaan tilawah Al-qur'an atau beribadah di salah satu karya besar arsitektur Islam.

\section{Al-Qur’an dan Sunnah Sebagai Sumber Seni}

Secara tegas Nasr memberikan pendapatnya mengenai sumber seni Islam bersumber dari dua sumber pokok ajaran Islam, yaitu Al-Quran dan Sunnah Nabi. Nasr mengatakan bahwa Al-Qur'an berisi kumpulan petunjuk bagi manusia agar ia mampu memenuhi janjinya kepada Tuhan, sebagai pusat kehidupan Islam dan merupakan dunia bagi umat Muslim. ${ }^{13}$ Secara umum pengertian Al-Qur'an bagi Muslim adalah sebuah kitab kumpulan petunjuk bagi manusia yang berasal dari Allah yang diturunkan kepada Rasullullah Muhammad melalui malaikat Jibril.

Al-Qur'an memiliki peranan paling utama dalam menjelaskan tentang keislaman yang didalamnya mencakup semua hal yang berkaitan dengan hukum-

${ }^{11}$ Abdul Hadi W.M., Hermeneutika, Estetika dan Religiusitas: Esai-esai Sastra Sufistik dan Seni Rupa, (Yogyakarta: Mahatari, 2004), hlm. 236-237.

${ }^{12}$ The Liang Gie, Filsafat Seni, (Yogyakarta: Pubib, 1996), hlm. 47-52.

${ }^{13}$ Nasr, Islam Antara Cita dan Fakta, hlm. 23.

32 | FaLASIFA, Vol. 10 Nomor 1 Maret 2019 
hukum dan bimbingan memahami Tuhan dengan benar. Dalam Islam khususnya kaum Asy'ariyah, Al-Qur'an secara teks bersifat sementara, tapi secara makna konseptual ia adalah kekal abadi sebagaimana Tuhan. Karena ia merupakan dzat Tuhan itu sendiri. Pandangan ini memang bertentangan dengan kaum Mu'tazilah yang menganggap bahwa Al-Qur'an sepenuhnya adalah makhluk, karena mereka adalah penganut rasio murni yang modern.

Umat Islam mempercayai bahwa Al-Qur'an adalah mukjizat dari Nabi Muhammad yang akan abadi sepanjang zaman. Menurut Oliver Leaman bahwa kemukjizatan $\mathrm{Al}$-Qur'an berada pada nilai estetika yang merupakan hasil kreasi yang luar biasa yang hal ini dapat dipercaya berasal dari Tuhan, ${ }^{14}$ walaupun ia menolak segala argument kemukjizatan Al-Qur'an yang diberikan oleh para pemikir Islam. Ini membuktikan kebesaran Al-Qur'an secara estetik memang sebuah kemukjizatan yang abadi yang sesuai dengan tantangan yang dilontarkan $\mathrm{Al}-\mathrm{Qur}$ 'an sendiri yang mempersilahkan siapapun membuat Al-Qur'an tandingan yang niscaya tidak akan dapat dilakukan. Nasr berpendapat bahwa kesucian Al-Qur'an menyebabkan semua yang terkait dengan bentuk Al-Qur'an juga suci. Bahasa Arab yang menjadi bahasa Al-Qur'an adalah bahasa suci umat Islam, karena ia terkait langsung dengan dzat Al-Qur'an yang memang turun dengan bahasa Arab.

Petunjuk yang berupa sejarah memberikan pengetahuan tentang sejarah orang-orang terdahulu dengan segala lika-liku kehidupannya. Pengetahuan ini dimaksudkan sebagai tamsil bagi para pembacanya untuk diambil hikmahnya dalam kehidupan berikutnya. Menurut Nasr pengetahun ini sebagai petunjuk bagi jiwa manusia agar selalu berada pada jalan yang lurus, seperti yang pernah dilakukan oleh para pendahulu. Al-Qur'an merupakan petunjuk yang memulai dari kelahiran sampai kematian, atau dari-Nya dan akan kembali kepada- Nya. Hal ini sebagai pengetahuan dasar teologi kepada Muslim yang beriman.

\section{Keindahan dan Seni Islami}

Estetika (aesthetics), sesuai dengan makna etimologisnya, ialah pengetahuan tentang objek-objek penikmat indra. Karya manusia yang dimaksudkan sebagai objek penikmat indra adalah karya seni. Sebagai cabang ilmu dan falsafah, estetika sering disamakan dengan teori seni, kritik seni dan falsafah keindahan. Tidak jarang juga disebut teori keindahan. ${ }^{15}$ Estetika sering diartikan sebagai filsafat keindahan atau seni. Tujuannya sebagaimana tujuan filsafat, dapat dirumuskan

\footnotetext{
${ }^{14}$ Oliver Leaman, Estetika Islam hlm.255.

${ }^{15}$ Abdul Hadi M.M, Hermeneutika, Estetika....hlm. 227.
} 
Titin Nurhidayati

mengikuti perumusan Harold Titus (1968), namun dengan mengaitkannya dengan masalah-masalah keindahan, yaitu (a) Menentukan sikap terhadap keindahan yang terdapat dalam alam, kehidupan manusia dan karya seni; (b) Mencari pendekatan-pendekatan yang memadai dalam menjawab masalah objek pengamatan indra, khususnya karya seni, yang menimbulkan pengaruh terhadap jiwa manusia, khususnya perenungan dan pemikiran, serta perilaku dan perbuatan manusia, (c) Mencari pandangan yang menyeluruh tentang keindahan dan objekobjek yang memperlihatkan rasa keindahan; (d) Mengkaji masalah-masalah yang berhubungan dengan bahasa dan penuturannya yang baik, sesuai keperluan, misalnya dalaam karya sastra, serta mengkaji penjelasan tentang istilah-istilah dan konsep-konsep keindahan; (e) Mencari teori untuk menentukan dan menjawab persoalan di sekitar karya seni dan obyek-obyek yang menerbitkan pengalaman indah. $^{16}$

Di sini keindahan dapat dibedakan menjadi keindahan yang bersifat sementara, yaitu keindahan zawahir (fenomenal) dan keindahan langgeng. Berkaitan dengan keindahan Al-Ghazali menyatakan dalam kitabnya Kimia Kebabagiaan bahwa peringkat-peringkat keindahan estetis sejajar dengan peringkat pengalaman kesufian. Ia berjalan dari peringkat syari'at (formal), melalui peringkat tarekat, menuju bakikat (ma'nawi) dan akhirnya ma'rifat. Pencapaian keindahan tertinggi dengan demikian melibatkan latihan spiritual. ${ }^{17}$ Imam al-Ghazali membagi keindahan sesuai dengan peringkatnya antara lain: 1) Keindahan indrawi (duniawi) dan nafsani (sensual) disebut juga keindahan lahir, yaitu keindahan yang berkaitan dengan hedonisme dan materialisme; 2) Keindahan alam, sangat bermanfaat karena dapat mendatangkan kesehatan kepada jiwa; 3) Keindahan akliyah atau rasional ialah keindahan yang tidak sepenuhnya dapat diserap oleh pancaindra, perasaan dan imajinasi, tetapi memerlukan perenungan dan pemikiran akal; 4) Keindahan rohaniyah atau irfani (mistik) berkaitan dengan akhlaq dan adanya pengetahuan tentang hakikat segala sesuatu pada diri seseorang atau karya sastra. Keindahan rohaniyah dapat dilihat pada pribadi Nabi. Nabi merupakan pribadi yang indah bukan semata-mata disebabkan kesempurnaan jasmani dan pengetahuannya tentang agama dan dunia, tetapi terutama karena akhlaknya yang mulia dan tingkat makrifatnya yang tinggi; 5) Keindahan Ilahiyah atau transendental. ${ }^{18}$

${ }^{16}$ Harold Titus, Living Issues in Philosophy, (New York: American Book Company, 1968), hlm. 6-9.

${ }^{17}$ Al-Ghazali, Kimia Kebahagiaan, Terj. Tim Mizan, (Bandung: Mizan, 1993), hlm.

${ }^{18}$ Abdul Hadi M.M, Hermeneutika, Estetika....hlm. 41-42, 231-232.

34 | FaLASIFA, Vol. 10 Nomor 1 Maret 2019 
Sebagaimana dikatakan oleh Nasr, Islam terdiri dari Hukum Ilahi (alSyariah), jalan spiritual (al-Tariqah) dan Hakikat (al-Haqiqah) yang merupakan sumber, baik Hukum maupun Jalan. ${ }^{19}$ Syari'ah berisi segala petunjuk praktis dari Tuhan berupa hukum-hukum yang mengatur pola hidup manusia sehari-hari agar di tidak keluar dari norma kehidupan manusiawi yang sempurna, serta menjadi dasar bagi perjalanan jiwa dari permukaan ke Pusat. ${ }^{20}$ Dan seseorang akan menjadi muslim jika menerimanya. Dan syari'ah adalah dimensi eksoterik dari Islam.

Tidak mungkin seorang muslim dapat memahami ajaran batin Islam tanpa memahami aturan-aturan hukum Islam dalam Syariah dan sebaliknya jika hanya memegangi ajaran lahir saja maka dia belum memahami ajaran Islam dengan sebenarnya. Keduanya terkait erat secara organis tidak boleh lepas satu dengan yang lain.

Pendapat Nasr yang demikian sejalan dengan pandangan seni dari Mohammad Iqbal yang dengan tegas mengatakan bahwa seni harus berhubungan dengan etika dan dia harus berada dibawah kendali moral, sehingga tidak ada yang disebut seni betapapun ekspresifnya seorang seniman kecuali ia mampu menimbulkan nilai-nilai yang cemerlang, menciptakan harapan-harapan baru, kerinduan dan aspirasi baru bagi peningkatan kualitas hidup manusia dan masyarakat. ${ }^{21}$ Keterikatan yang sangat kuat antara agama dan karya seni budaya seperti yang terlihat di atas disatu sisi memang mempunyai pengaruh yang positif, yaitu selalu terpeliharanya nilai-nilai etik yang ada sepanjang jaman. Hal ini sempat kacau pada era modern dengan banyak disinyalir mulai tergradasinya nilai-nilai universal yang tinggi. Seni tidak hanya sebatas karya yang berupa obyek hiburan semata yang diukur secara material ansich berdasar nilai pasar. Makna yang terkandung di dalamnya tetap terpelihara dengan baik. Kandungan makna yang dalam menjadi nilai spiritual yang tinggi yang menghubungkan manusia dengan Tuhan. Visi keilahian mensyaratkan segala sesuatu harus suci, terhindar dan terlepas dari unsur duniawiah yang buruk.

Akan tetapi yang demikian juga mempunyai dampak kurang bagus pula dalam perkembangan kreatifitas seni. Aturan yang ada dalam Al-Qur'an dan Sunnah terbatasi dalam bentuk teks suci yang masih memerlukan penafsiran atau interpretasi. Bahkan menurt Palmer, manusia mulai bangun tidur di pagi hari

${ }^{19}$ Nasr, Spiritualitas..., hlm. 15.

${ }^{20}$ Nasr, Islam Antara Cita dan Fakta, hlm. 89.

${ }^{21}$ Khudori Sholeh, Wacana Barn Filsafat Islam, (Yogyakarta: Pustaka Pelajar, 2004), hlm. 309. Lebih jelas lagi lihat: Syarif Iqbal. Tentang Tuban dan Keindahan, terj. Yusuf Jamil, (Bandung: Mizan, 1993), hlm. 133.

FALASIFA, Vol. 10 Nomor 1 Maret 2019 | 35 
Titin Nurhidayati

hingga tidur kembali terus melakukan Penafsiran. ${ }^{22}$ Bahkan dalam kondisi tidur pun manusia mampu mendapatkan pengetahuan dan tentunya masih dapat diinterpretasikan.

\section{Bentuk-bentuk Seni}

Secara kongkret Nasr membicarakan beberapa bentuk seni yang ada. Nasr mengedepankan bentuk kaligrafi, arabes dan geometri sebagai bentuk-bentuk pencapaian tertinggi dari seni Islam. ${ }^{23}$ Adapun geometri yang disakralkan adalah geometri Pythagorean menurut Ibn Sina dan Al-Farabi yang memulai dari titik dan melahirkan garis-garis dan bentuk, yang hal ini merefleksikan dari Yang Satu mengalir ke yang banyak. ${ }^{24}$

Dalam pandangan Nasr bentuk seni suci adalah seni plastis yang berupa seni kaligrafi, arsitektur masjid. Kemudian seni suara yang suci adalah pembacaan (tilawah) Al-Qur'an dan musik spiritual yang mengiringi tarian mistik (sama') dalam tarekat Mawlawiyyah. ${ }^{25}$ Selain itu di kategorikan sebagai seni tradisional semisal Syair atau puisi-puisi sufi serta prosa-prosa sufi, atau seni pertunjukan dalam tradisi Syi'i yang bernama ta'ziyah.

Berikut akan dibahas mengenai bentuk-bentuk seni yang dimaksud Nasr dengan memberikan pengertian dan jenis yang biasa dipakai agar lebih muda di pahami. Sekaligus melihat sejauh mana pandangan Nasr yang Persian sentris dalam hal seni.

\section{Seni Musik}

Musik merupakan kawan manusia sehari-hari dalam setiap kesempatan. Seni ini termasuk seni suara yang memperlihatkan keindahan dari suara yang berasal dari alat-alat yang dapat mengeluarkan suara, termasuk manusia sendiri. Hazrat Inayat Khan mengatakan bahwa musik adalah miniatur keseluruhaan keharmonisan alam semesta, karena keharmonisan alam semesta adalah musik itu sendiri; dan manusia sebagai miniaturnya harus menunjukkan keharmonisan yang sama, dalam pulsasinya, dalam detak jantungnya dan dalam vibrasinya dia menunjukkan ritme dan nada, perpaduan nada harmonis atau tidak harmonis,

${ }^{22}$ Richard, E. Palmer, Hermeneutika: Teori Baru Mengenai Interpretasi, Terj, Masnur Hery dan Damanhuri Muhammed, (Yogyakarta: Pustaka Pelajar, 2003), hlm. 9.

23 Abdul Hadi W.M, Seni Islam dan Akar-akar Estetikanya dalam Estetika Islam Menafsir seni dan Keindahan oleh Oliver Leaman, terj. Irfan Abubakar, (Bandung: Mizan, 2005), hlm. 14.

${ }^{24} \mathrm{Ibid}, \mathrm{hlm} .15$.

${ }^{25}$ Seyyed Hossein Nasr, Spiritualitas dan Seni Islam, hlm. 84-94.

36 | FaLASIFA, Vol. 10 Nomor 1 Maret 2019 
kesehatannya atau sakitnya, kenikmatannya atau ketidaknyamanannya. ${ }^{26}$

Menurut Nasr, musik berfungsi untuk menentramkan pikiran beban kemanusiaan (basyariyyah) dan menghibur tabiat manusia, dan juga sebagai stimulan untuk melihat rahasia ketuhanan (asrar-i rabbani), ${ }^{27}$

Seorang ulama kontemporer juga terjebak dalam pandangan yang demikian. Abdurrahman al-Baghdadi misalnya, ia mengulas panjang lebar tentang hukum seni dan tari dari ilmu figh. Ia memberikan kesimpulan bahwa seni musik dan tari hukumnya yang tertinggi adalah mubah, bahkan bisa turun menjadi makruh dan haram. Berdasarkan dalil-dalil hadits yang dia temukan ia memberikan syaratsyarat yang sangat kaku dalam musik dan tari. Misalnya seorang penyanyi wanita diharamkan menyanyi di atas panggung terbuka yang dilihat banyak orang, atau juga tidak boleh wanita dibayar dalam menyanyi. ${ }^{28}$

Akan tetapi kesakralan sebuah suara yang keluar dari sebuah alat musik tidak harus berasal dari alat musik Persia. Kenyataannya setiap musik tidak harus berasal dari alat musik dari Persia. Kenyataannya setiap daerah mempunyai sebuah alat musik tradisional yang khas yang memiliki kesakralan. Sebuah bedug di Jawa jika di pukul menimbulkan suara yang gemuruh yang menandakan waktu sholat dan menarik perhatian dan minat Muslim untuk menuju masjid guna melakukan ibadah shalat, ini barangkali sebanding dengan suara yang dihasilkan dari petikan senar. Kamanchah yang khas Persia sebagai sebuah suara yang membangkitkan kesadaran Jiwa. Musik orkes gambus di Indonesia misalnya dengan menggunakan alat musik yang beraneka ragam menghasilkan suara yang juga menuntun kepada penghayatan tentang ketuhanan. Bahkan Sunan Bonang sangat dikenal karena kemahirannya memainkan alat musik tradisional bernama Bonang, yang kalau beliau yang memainkan maka banyak orang tertarik mendengarkan dakwahnya karena kesakralan suara dan pemainnya. Dan masih banyak lagi.

\section{Seni Sastra}

Bentuk seni yang lainnya yang diketengahkan oleh Nasr adalah seni sastra. Ia merupakan salah satu bentuk seni yang menitikberatkan pada olah rasa dan keindahan yang dituangkan dalam bahasa. Pesan pesannya ditampilkan dalam kata dan kalimat yang membentuk sebuah prinsip keselarasan dan irama, yang juga mengatur alam semesta; keselarasan itu terkandung dalam kata atau substansi

${ }^{26}$ Hazrat Inayat Khan, The Heart of Sufism, terj. Andi Haryadi, (Bandung: Remaja Rosdakarya, 2002), hlm. 300.

${ }^{27}$ Nasr, Spiritualitas..,hlm. 169.

${ }^{28}$ Abdurrahman al-Baghdadi, Seni Dalam Pandangan Islam: Seni Vokal, Musik dan Tari, (Jakarta: Gema Insani Press, 2004), hlm. 92-100.

FALASIFA, Vol. 10 Nomor 1 Maret 2019 | 37 
Titin Nurhidayati

bahasa dan melalui Syair akan menggema kembali keselarasan yang fundamental yang memungkinkan manusia kembali pada keberadaan dan kesadarannya yang lebih tinggi. ${ }^{29}$

Di atas telah disinggung bahwa bahasa merupakan sebuah ungkapan yang berbentuk simbol-simbol yang memiliki pesan makna. Gadamer mengatakan bahwa bahasa haruslah dipahami sebagai penunjuk secara historis dengan kesejarahan makna-maknanya, tata bahasa dan sintaksisnya, sehingga bentuk bahasa menjadi logika variatif dari pengalaman, hakikat, dan juga pengalaman historis dan tradisi yang mencakup pengalaman supernatural atau spiritual. ${ }^{30}$

Seni sastra termasuk di dalamnya berupa syair (puisi), Syi'ir (nadzm) dan prosa sebenarnya sebuah karya seni yang secara langsung bercerita mengenai pengalaman-pengalaman sang seniman dalam menapaki kehidupan. Sebuah pengalaman dapat dirasakan dan dalam menapaki kehidupan. Sebuah pengalaman dapat dirasakan dan diambil maknanya keudian dikomunikasikan kepada orang lain melalui bahasa. Setiap bahasa yang ada di dunia ini memiliki arti dan penunjukkan ungkapan yang berbeda-beda. Tetapi mempunyai substansi sama.

Disisi lain setiap bahasa yang ada selalu memiliki keindahannya sendiri. Nasr sangat memuji keindahan bahasa Persia karena ia orang Persia. Rasa yang ada di jiwa Nasr akan berbeda dengan rasa di jiwa orang bukan Persia walaupun samasama memakai bahasa Persia. Hal ini dikarenakan pengaruh historis dan peresapan sebuah ungkapan dalam kehidupan sehari-hari. Orang yang setiap harinya menggunakan bahasa Persia ia akan mendapatkan kedalaman sebuah makna ungkapan dari kata- kata yang ia ucapkan. Berbeda halnya dengan orang yang baru menggunakan bahasa persia walaupun ia tahu artinya, karena arti yang ia tahu masih sangat terbatas.

Demikian beberapa contoh karya puisi dan prosa yang berada di Persia. Perlu diingat kembali bahwa bahasa apapun memiliki nilai sastra yang sama tingginya jika kita dapat merasakan kehadiran maknanya yang dalam bermula dari kata yang kita baca dan ucapkan.

\section{Seni Tari}

Seni tari merupakan bentuk kesenian yang menampilkan keindahan gerak yang biasanya diiringi dengan alunan musik. Prinsip keselarasan dan keharmonisan menjadi prinsip pokok dalam seni tari. Suatu gerakan haruslah harmonis dengan

\footnotetext{
${ }^{29}$ Lebih jelas uraian ini lihat, Ibid, hlm. 100-101.

${ }^{30}$ H.G. Gadamer, Truth and Method. New York: The Scabury Pres, 1965), hlm.
} 394.

38 | FalasIFA, Vol. 10 Nomor 1 Maret 2019 
alunan musik yang mengiringi, juga harus selaras tempo gerak dan pesan yang dikandung.

Seni tari termasuk dalam seni suci saat ia berintegrasi dengan musik spiritual, sehingga menghasilkan tarian yang berdimensi spiritual juga seperti pada sama ${ }^{31}$ pada tarekat Mawlawiyah. Dalam tarekat ini tarian berupa gerak berputar tubuh yang berkeliling mengikuti irama musik yang dibunyikan yang merefleksikan keadaan ekstase jiwa. ${ }^{32}$ Keadaan ini merupakan manifestasi keadaan spiritual batin sang sufi dalam menapaki dimensi batin.

Sebagaimana dijelaskan di atas, musik membantu mengantarkan manusia menembus alam transenden, mempercepat perenungan-perenungan yang dilakukan yang disebabkan karena harmonisasi alunan dan ritme nada-nadanya. Tarian selalu diiringi dengan musik, yang sebenarnya tarian itu adalah musik yang bergerak tanpa suara. Tarekat Mawlawiyah sebagai contohnya.Tarian dengan demikian juga sangat erat kaitannya dengan dunia sufi.

\section{Seni Rupa}

Bentuk seni ini memiliki kekhasan dengan cara memanfaatkan media warna. Nasr mengkategorikan jenis seni ini sebagai jenis seni plastis. Dalam kategori ini kesuciannya diwakili dengan kaligrafi. Kaligrafi adalah lukisan yang dituangkan dari indahnya warna-warna membentuk sebuah tulisan Arab dari sumber AlQur'an atau Sunnah.

Nasr mengatakan bahwa kaligrafi adalah geometri spirit, huruf-huruf, katakata dan ayat-ayat Al-Qur'an bukanlah sekedar unsur-unsur dari suatu bahasa tulis, tetapi adalah makhluk-makhluk atau personalitas-personalitas dengan kaligrafi sebagai bentuk fisikal dan visualnya. ${ }^{33}$ Adapun secara mistis, kaligrafi menggunakan prinsip geometri mistis Pythagorean yang dimulai titik yang satu menghasilkan garis yang banyak. Dengan demikian kaligrafi merupakan sebuah seni yang langssung berhubungan dengan Al-Qur'an dan Tuhan sehingga masuk kategori seni suci.

Akan tetapi Nasr tidak menampilkan lukisan miniatur yang juga dihasilkan oleh para sufi di Persia, Indo Pakistan dan Asia Tengah yang cenderung menampilkan lukisan realisme dan bahkan impresionisme yang salah satu

${ }^{31}$ Adalah tarian mistik kaum sufi Mawlawi dengan berputar-putar keliling yang merupakan seni suci esoteris yang berusaha memungkinkan manusia untuk merasakan pengalaman spiritual dan berintegrasi ke dalam Pusat utama. Lihat Nasr, Spiritualitas....hlm. 94.

${ }^{32}$ Al-Bagdadi, Seni...hlm. 85.

${ }^{33}$ Nasr, Sporitualitas... hlm. 28. 
bentuknya berupa lukisan miniatur yang menampilkan sosok manusia secara penuh. ${ }^{34}$ Dalam kenyataannya bahwa menampilkan lukisan dalam Islam memang sangat dibatasi dalam wilayah realisme. Hal ini didasarkan pada sebuah alasan bahwa sebuah keindahan pada kesucian tidak dapat dilukiskan secara real. Pandangan ini disebut anakronisme. Jika misalnya Tuhan dilukiskan dengan realitas maka saat itu juga telah tereduksi secara besar-besaran hakekat ketuhanannya. Yang terjadi adalah sebuah hasil karya yang tidak suci dan bahkan tidak Islami. Tidak akan dapat dilukiskan keindahan Yang Maha Indah melainkan hanya dapat diungkapkan dengan tulisan Arab suci dalam sebuah kaligrafi. Hal ini juga berlaku untuk penggambaran Nabi Muhammad yang tidak diperbolehkan secara realistis.

\section{Seni Arsitektur}

Bentuk seni yang terakhir ini lebih komplek lagi cara menciptakannya dan dasar-dasar prinsip penciptaannya. Sebagai contoh adalah bangunan masjid. Material bangunan masjid tradisional sebenarnya sama dengan material dari candi-candi atau gereja-gereja yang ada. Akan tetapi bila seorang Muslim berdoa di dalam masjid akan merasakan sakralitas yang dalam dibanding jika dilakukan di gereja. Hal ini dikarenakan adanya kesatuan kolektif yang ada pada materialmaterial itu sevara organik yang membentuk sebuah dunia spiritual yang berbeda prinsip dan kesatuan inilah yang menjadi dasar seni arsitektur. ${ }^{35}$

Kesatuan dari bentuk dan material ini mewujudkan simbol komplek yang menjadi pusat spiritualitas berkumpul. Nasr mencontohkan sebuah bentuk suci Ka’bah. Ia mengatakan:

"Arsitektur suci Islam yang paling awal adalah ka'bah dengan titik poros langit yang menembus bumi. Monument primordial yang dibangun oleh Nabi Adam dan kemudian dibangun kembali oleh Nabi Ibrahim ini, merupakan refleksi duniawi daari monument surgawi yang juga terpantul dari hati manusia. Keselarasan dimensi-dimensi Ka’bah, keseimbangan dan simetrisnya, pusat dari kosmos Islam daapaat ditemukan dalam arsitektur suci di seluruh dunia Islam.”36

Keseimbangan bentuk materialnya menggambarkan keseimbangan kosmos yang merupakan hukum Tuhan. Bentuk simestris merupakan salah bentuk bangun

\footnotetext{
${ }^{34}$ Abdul Hadi, WM, Seni Islam, (Jogjakarta,Pelita Press,2003), hlm. 15.

${ }^{35}$ Nasr, Spiritualitas....hlm. 50.

${ }^{36}$ Ibid, hlm. 54.
}

40 | Falasifa, Vol. 10 Nomor 1 Maret 2019 
geometrik yang melambangkan keteraturan langkah dalam penapakan jalan kehidupan.

Karya seni arsitektur juga dilandasi dengan pengetahuan dan teknologi yang tinggi yang merupakan sebuah pencapaian pemikiran dari sebuah peradaban yang terus berkembang. Teknologi yang dipakai dilandasi dengan nilai spiritual yang tinggi ini menghasilkan sebuah karya kesatuan bentuk yang indah. Keindahan lengkungan kubah mesjid bersumber dari lengkung geometris spiritual yang menyatu pada puncak tertinggi berupa sebuah titik pusat melambangkan Realitas Tertinggi yang Maha Tunggal. Ini dilengkapi dengan ornamen kaligrafi dan lukisan geometris dengan corak warna yang indah memberikan sebuah makna mendalam tentang kebesaran Tuhan. Lukisan ini berada di atas di dalam kubah yang menyimbolkan alam semesta yang kesemuanya dilingkupi oleh Yang Maha Tunggal.

\section{Aplikasi Konsep Keindahan dan Seni Islami Seyyed Hossein Nasr dalam Dunia Pendidikan Islam}

Dalam konsep islam, begitu kata Nasr, pendidikan islam mengimplikasikan bukan sekedar pengajaran atau penyampaian (ta'lim), tapi juga pelatihan seluruh diri siswa (tarbiyah). Menurut Nasr guru bukan sekedar seorang muallim "penyampaian pengetahuan" tetapi juga seorang murabbi "pelatih jiwa dan kepribadian". Sistem pendidikan islam, demikian lanjut Nasr, tidak pernah memisahkan pelatihan pikiran dari pelatihan jiwa dan keseluruhan pribadi seutuhnya, ia tidak pernah memandang alih pengetahuan (transfer of knowledge) dan pemerolehan yang abash tanpa dibarengi pemerolehan kualitas-kualitas moral dan spiritual. ${ }^{37}$ Dengan kata lain, pendidikan sebagaimana yang diinginkan Nasr adalah terciptanya insan-insan yang memiliki kualitas intelektual dan kualitas spiritual. Antara pengembangan fakultas fikir dan fakultas dzikir dapat berjalan secara serasi dan seimbang.

Menurut Nasr pendidikan islam meliputi seluruh kehidupan muslim, hal ini tampak dalam fase-fase dan periode-periode dalam keseluruhan organik. Pertamatama, dalam periode primer pendidikan keluarga masa awal baik bapak maupun ibu memerankan peran guru di dalam persoalan-persoalan keagamaan dan juga persoalan yang berhubungan dengan agama, kebudayaan dan adat. ${ }^{38}$

Dalam perwujudan pendidikan, perbuatan atau kerja merupakan realisasi

37 Seyyed Hossein Nasr, Islam Tradisi di Kancah Dunia Modern, Terj. Lukman Hakim, (Bandung: Pustaka, 1994), hlm. 125

${ }^{38}$ Ibid, hlm. 126 


\section{Titin Nurhidayati}

akal. Akal bekerja untuk memahami kebenaran secara utuh, melalui pikiran yang memikirkan alam, manusia dan sejarah, sedangkan melalui qolbu-nya, ia memahami firman-firman Tuhan dan sunnah Allah dalam kehidupan alam semesta. Perbuatan dalam pengertian pendidikan adalah tidak dapat dipisahkan dari akal, baik pikiran maupun qolbu. Dalam kaitan ini, maka perbuatan dalam pengertian pendidikan adalah proses mewujudkan konsep-konsep, serta rencanarencana dalam kenyataan. Perbuatan ini pada dasarnya adalah perbuatan kreatif, karena tersimpan dalam proses penciptaan. Dalam tahap perbuatan kreatif ini terjadi hubungan yang dialektis antara manusia dengan alam sekitarnya. Ia memilih bahan yang ada, mengolah dan memberi bentuk. Dalam bentuk yang baru 'dalam pendidikan' manusia memberikan nilai, baik nilai yang intrinsic yang ada pada pendidikan itu sendiri, maupun nilai ekstrinsik yang berada dalam praktek pendayagunaan pendidikan untuk tujuan dan kepentingan manusia.

Perbuatan kreatif pada dasarnya tidak dapat dipisahkan dengan nilai-nilai, baik nilai estetika, logika ataupun etika. Dalam praktek penciptaan lembagalembaga pendidikan itu mempunyai nilai keindahan. Kemudian nilai logika memberikan tuntutan untuk menyusun konsep dan rencana-rencana kerja yang masuk akal. Sedangkan nilai etika memberikan batasan-batasan agar perbuatan kreatif itu tetap berada dalam wawasan moral dan untuk tujuan moral.

Perbuatan kreatif tidak dapat dipisahkan dari akal, baik dengan pikiran maupun qolbu. Perbuatan yang terlepasdari pikiran dan qolbu, pada dasarnya tidak dapat disebut pendidikan. Perbuatan yang dilepaskan dari akal, terlepas dari kesatuan pikiran dan qolbu, akan mengakibatkan peserta didik jatuh pada perbuatan yang jelek, karena pikiran yang terbelah dengan qolbu-nya menjadikan manusia dapat dikuasai oleh hawa nafsunya. Pada tingkat ini perbuatan manusia cenderung ke arah yang kotor.

Pendidikan dalam Islam, antara lain diarahkan kepada pengembangan jasmani dan rohani manusia secara harmonis serta pengembangan fithrah secara terpadu. Sehingga pendidikan Islam dapat difungsikan sebagai sarana bagi pemecahan masalah-masalah hidup dan kehidupan, pengembangan ilmu pengetahuan dan teknologi, serta budaya manusia dan pengembangan sikap iman dan takwa kepada Allah swt.

Setelah mental terbentuk, dilanjutkan dengan langkah-langkah pembentuan "mission statement" melalui dua kalimat syahadat, kemudian pembangunan karakter melalui shalat lima waktu sehari semalam, pengendalian diri melalui puasa. Kemudian pembentukan kecerdasan sosial melalui zakat dan haji. Semua itu merupakan struktur sistem pembinaan dengan strategi dan metode training pendidikan ideal. Pembinaan kecerdasan intelektual, emosional dan spiritual secara

42 | Falasifa, Vol. 10 Nomor 1 Maret 2019 
komprehensif melalui rukun iman dan rukun Islam adalah proses pengaktualisasian diri sendiri secara totalitas. Potensi luar diri manusia yang bersumber dari ruh dan futhrah Allah, inilah inti ibadah.

Dengan kata lain bahwa aktualisasi tanggung jawab manusia terhadap Tuhan dalam pendidikan Islam tidak bisa dipisahkan dengan tanggung jawab manusia terhadap diri sendiri. Hal ini dikarenakan dengan keberadaan manusia itu sendiri sebagai makhluk ciptaan-Nya. Manusia merupakan makhluk pilihan Allah yang mengembangkan tugas ganda, yaitu sebagai khalifah Allah dan 'abdullah (abdi Allah). Untuk mengaktualisasikan kedua tugas tersebut, manusia dibekali dengan sejumlah potensi didalam dirinya. Potensi-potensi tersebut berupa ruh, nafs, qalb dan fithrah.

Pada hakikatnya, proses pendidikan merupakan aktualisasi potensi diri manusia. Sistem proses menumbuhkembangkan potensi diri itu telah ditawarkan secara sempurna dalam sistem ajaran Islam, ini yang pada akhirnya menyebabkan manusia dapat menjalankan tugas yang telah dibebankan Allah. Pengaktualan potensi diri manusia tersebut dapat diarahkan melalui konsep pembinaan "kecerdasan emosional dan spiritual".

\section{KESIMPULAN}

Pertama Nasr menawarkan solusi untuk menghadirkan kembali seni yang Islami di era modern saat ini. Seni adalah seni yang didasarkan atas ajaran AlQur'an dan Sunnah. Sebuah karya seni harus memancarkan dimensi ketuhanan sebagaimana diajarkan dalam Al-Qur'an yang telah dijelaskan dengan Hadits Nabi. Pancaran itu oleh Nasr disebut sebagai al-barakah al-Muhammadiyyah. Seni islami dibagi tiga jenis, yaitu: (1) Seni suci adalah seni yang berhubungan langsung dengan praktik-praktik utama agama dan kehidupan spiritualitas, yang mencakup seni-seni seperti kaligrafi, arsitektur masjid, dan tilawah Al-Qwran. (2) Seni tradisional, ialah seni yang melukiskan prinsip-prinsip wahyu Islam dan spiritualitas Islam namun tidak dimanifestafikan dengan secara langsung. Dalam beberapa hal seni suci merupakan inti dari seni tradisional yang secara langsung menggambarkan norma dan prinsip yang tidak direfleksikan secara langsung oleh seni tradisional. Hal ini dimaksudkan agar karya seni yang dihasilkan mempunyai pijakan yang jelas yang bersumber dari Realitas Tertinggi.

\section{DAFTAR PUSTAKA}

al-Baghdadi, Abdurrahman. 2004. Seni Dalam Pandangan Islam: Seni Vokal, Musik dan Tari. Jakarta: Gema Insani Press.

Al-Ghazali. 1993. Kimia Kebahagiaan, Terj. Tim Mizan. Bandung: Mizan. 
Titin Nurhidayati

Gie, The Liang. 2005. Filsafat Seni: Sebuah Pengantar. Yogyakarta: PUBIB.

Hadi, Abdul. 2004. Hermeneutika, Estetika dan Religiusitas: Esai-esai Sastra Sufistik dan Seni Rupa. Yogyakarta: Mahatari.

2003. Seni Islam. Jogjakarta: Pelita Press.

Jakob. 2000. Filsafat Seni. Bandung: Penerbit ITB.

Nasr, Seyyed Hossein. 2001. Islam antara Cita dan Fakta, terj. Abdurrahman Wahid dan Hasim Wahid. Yogyakarta: Pusaka.

1964. An Introductiont to Islamic Cosmological Doctrines.

Cambridge: Harvard University Press.

. 1993. Spiritualitas, Krisis Dunia Modern dan Agama Masa

Depan. Jakarta: Paramadina.

. 1986. Science and Civilization in Islam, terjemahan: J.

Mahyudin. Bandung: Pustaka.

. 2003. Sufisme Persia Awal, terj. Gafna Raiz Wahyudi,. Yogyakarta: Pustaka Sufi.

1993. Spiritualitas dan Seni Islam. Terj. Sutejo. Bandung:

Mizan.

. 1972. Sufi Essays. New York: University of New York

Press.

1996. Tentang Tradisi dalam Perenialisme: Melacak Jejak

Filsafat Abadi, (ed.) Ahmad Norma Permata. Yogyakarta: Tiara Wacana.

. 2004. Intelegensi dan Spiritualitas Agama-agama. Terj.

Suharsono dkk. Jakarta: Inisiasi Press.

. 1994. Islam Tradisi di Kancah Dunia Modern, Terj.

Lukman Hakim. Bandung: Pustaka.

2003. The Heart of Islam, Terj. Nurasiah Fatih Sutan

Harap. Bandung: Mizan.

Oliver, Leaman. 2005. Estetika Islam: Menafsir Seni dan Keindahan, terj. Irfan. Bandung: Mizan.

Soleh, A. Khudori. 2004. Wacana Baru Filsafat Islam. Yogyakarta: Pustaka Pelajar.

2013.Filsafat Islam Dari Klasik Hingga Kontemporer,

Yogyakarta: Ar-Ruzz Media.

44 | FaLASIFA, Vol. 10 Nomor 1 Maret 2019 